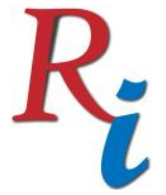

Asia Proceedings of Social Sciences

(APSS)

www.readersinsight.net/APSS

\title{
RE-EXAMINING THE LINK BETWEEN FINANCE AND ECONOMIC GROWTH IN NIGERIA: THE GREGORY AND HANSEN(1996) COINTEGRATION APPROACH
}

Sunday Elijah*

Department of Economics,

Federal University Gusau, Zamfara State

Nigeria.

Department of Economics,

Faculty of Economics and Management, Universiti Putra Malaysia

Malaysia.

\section{Namadina Hamza}

Department of Economics,

Federal University Gusau, Zamfara State

Nigeria.

*Corrosponding author’s Email: elijahsundayecons@gmail.com

Peer-review under responsibility of $3^{\text {rd }}$ Asia International Multidisciplanry Conference 2019 editorial board (http://www.utm.my/asia/our-team/) (c) 2019 Published by Readers Insight Publisher, lat 306 Savoy Residencia, Block 3 F11/1,44000 Islamabad. Pakistan, info@ readersinsight.net This is an open access article under the CC BY-NC-ND license (http://creativecommons.org/licenses/by-nc-nd/4.0/). 


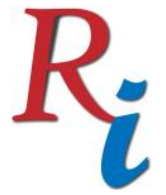

Asia Proceedings of Social Sciences

(APSS)

www.readersinsight.net/APSS

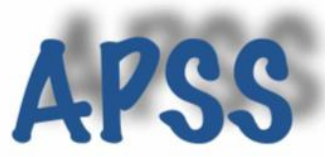

\section{Rese a r ch H i g h I igh t}

The financial sector is considered as vital in the process of growth of economies both developed and developing. Economists and researchers have sough to investigate the relationship between duo with conflicting and incnclusive results. Hence, in a developing country like Nigeria, the results remains same. Example, Akinlo (2010) finds a significant positive relationship between development of the financial sector and economic growth. Other studies like Nyong (1997) find a significant negative relationship between finance and economic growth.Therefore, this study seeks to re-examine the relationship between Nigeria's finance and economic growth using annual time series data from 1981 to 2015. Similarly, it seeks to find out if there exist a structural break in the data and whether it matters in determining the relationship between finance and economic growth.The study finds a signifcant negative relationship between finance and econmic growth after accounting for structural break and that inclusion of break in the estimated model enhance its performance.The study recommends that future macroeconomic studies should check for breaks and if present be considered in estimation of such models.

\section{Research Objectives}

The research aim is to re-investigates the link in finance and economic growth in Nigeria using an annual time seriess data between 1986 and 2015. It seesks to find out if there is break in the data, therefore, the paper seeks to re-examine the relationship between finance and economic growth with and without structural breaks using the Gregory and Hansen (1996b) approach.

\section{Methodology}

The study employs annual time series dataset from 1981 to 2015 which is sourced in various editions of the Central Bank of Nigeria. The data was tested for the presence of unit root using the Augmented Dickey-Fuller (1987) and Phillips-Perron unit roots test, it was found that the series are $I(1)$.To check for the stationarity of the series while also accounting for structural breaks, the Zivot and Andrews test for the presence of one structural-break also indicates the series is non-startionary at level, but stationary at first difference with the break date identified as 2010. Having identified structural break, the Gregory and Hansen (1996a) methodology was applied, and it consisits of four models: level shift, level shift with trend, model with shifts affecting the slope and interceps and also model with regime shifts. The model is estimated using the Vector error correction model with out the break and also with the break period represented as a dummy variable. The estimated model was also subjected to post diagnostic checking such as test for the normality of the residuals, test for the presence of serial correlation as well test for the stability of the residuals of estimated parameters of the model.

\section{Results}

The results Augmented - Dickey Fuller and Phillips and Perron o test for stationarity indicates that the variables are not stationary at its level values, but after first difference they become stationary. The Zivot and Andrews unit root test also for one structural break indicates that the level values of the series are none stationary but becomes staionary at first difference.

The Gregory and Hansen cointegration methodology hsa confirmed the exisstence of cointegration with one edogenously determined breaks which confirms the results of the Zivot and Andrews unit roots test.The presence of cointegration leads to the estimation of the long run relationship between finance and economic growth, the results of the vector error correction 


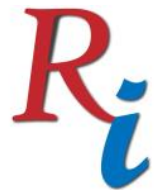

\section{Asia Proceedings of Social Sciences \\ (APSS) \\ www.readersinsight.net/APSS}

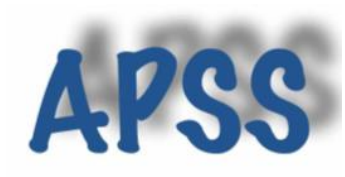

model shows that finance has a significant positive relationship with economic growth. On the other hand, wheen the structural period was accounted for in the vector error correction model, there exist a negative and significant relationship between finance and economic growth.The results of the diagnostic tests indicates that the estimated model is devoid of serial correlation, residuals are normally distributed and the model is found to be statble.

\section{Findings}

The findings from the study indicates that there is a significant positive long run relationship between development of the financial sector and economic growth in Nigeria in the study period. However, the study also finds out after accounting for the structural break period that there exixst a signioficant negative relationship between financial sector development and economic growth in Nigeria, which may not be unconnected with the fact that Nigeria been an oil dependent economy despite financial sector development, any shock in the international oil market could adversely affects its growth, coupled with the fact that the financial sector developments could divert away investment in the real sector which could affect negative its economic growth.The study also finds out that accounting for breaks is important in macroeconomic models estimation, because the model that includes structural-break performs better in terms of its explanatory power of the effect of the independent variables on the economic growth.

\section{References}

Akinlo, A. E., \& Egbetunde, T. (2010). Financial Development and Economic Growth: The Experience of 10 Sub-Saharan African Countries Revisited. The Review of Finance and Banking, 02(1), 17-28.

Dickey, D. A. F., Wayne A. (1987). Likelihood ratio statistics for autoregressive time series with a unit root. Econometrica: Journal of the Econometric Society, 1057-1072.

Gregory, A. W., \& Hansen, B. E. (1996a). Practitioners corner: tests for cointegration in models with regime and trend shifts. Oxford bulletin of Economics and Statistics, 58(3), 555-560.

Gregory, A. W., \& Hansen, B. E. (1996b). Residual-based tests for cointegration in models with regime shifts. Journal of econometrics, 70(1), 99-126.

Nyong, M. O. (1997). Capital market development and long-run economic growth: Theory, evidence and analysis. First Bank Review, 4, 13-38. 